\title{
Aberrant histone methylation and the effect of Suv39H1 siRNA on gastric carcinoma
}

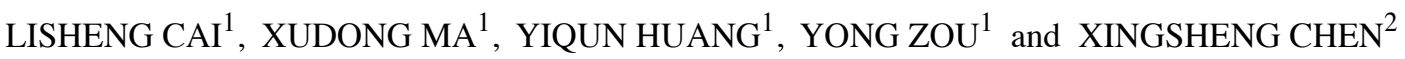 \\ ${ }^{1}$ Zhangzhou Affiliated Hospital of Fujian Medical University, Zhangzhou, Fujian 363000; \\ ${ }^{2}$ United Hospital of Fujian Medical University, Fuzhou, Fujian 350001, P.R. China
}

Received February 17, 2014; Accepted March 21, 2014

DOI: 10.3892/or.2014.3135

\begin{abstract}
The present study aimed to investigate the involvement of the Suv39H1 histone methyltransferase in the epigenetic changes in the euchromatic promoter in gastric carcinoma. We retrospectively analyzed the protein of Suv39H1 and tri-methylated histone H3 lysine 9 (H3K9) and histone H3 lysine 4 (H3K4) in 175 cases of gastric carcinoma by immunohistochemistry. Suv39H1 was depleted by siRNA, and cell apoptosis and cell proliferation were assessed by TUNEL and MTT assays, respectively. Histone methylated $\mathrm{H} 3 \mathrm{~K} 9$ and histone acetylated $\mathrm{H} 3$ and $\mathrm{H} 4$ were evaluated by western blotting. We found that the expression of Suv39H1 and tri-methylated H3K9 in gastric carcinoma was higher than that in benign gastric diseases $(\mathrm{p}<0.05)$. Tri-methylated H3K4 was similar in both tissue types ( $>0.05)$. Both Suv39H1 and trimethylated H3K9 were positively correlated with the degree of differentiation, depth of infiltration and lymphatic invasion $(\mathrm{p}<0.05)$ in gastric carcinoma. In addition, tri-methylated H3K9 was positively correlated with tumor stage, and node and metastatic statuses $(\mathrm{p}<0.05)$. Activation of Suv39H1 and overexpression of $\mathrm{H} 3 \mathrm{~K} 9$ tri-methylation may play an important role in tumorigenesis. They may be useful as a predictor for poor prognosis in gastric carcinoma. Silencing of the Suv39H1 gene decreased tri-methylated $\mathrm{H} 3 \mathrm{~K} 9$ and increased histone $\mathrm{H} 3$ acetylation, which caused activation of gene transcription, while there was no change in histone $\mathrm{H} 4$ acetylation. Depletion of Suv39H1 induced apoptosis and inhibited cell proliferation in the gastric cancer MGC803 cell line, while decreasing
\end{abstract}

Correspondence to: Professor Xudong Ma, Department of Hematology, Zhangzhou Affiliated Hospital of Fujian Medical University, Zhangzhou, Fujian 363000, P.R. China

E-mail: xudongma05@yahoo.com

Abbreviations: H3K9, histone $\mathrm{H} 3$ lysine 9; $\mathrm{H} 3 \mathrm{~K} 4$, histone $\mathrm{H} 3$ lysine 4; K, lysine; HMT, histone methyltransferase; PML, promyelocytic leukemia; RB, retinoblastoma protein; TNM, tumornode-metastasis; PCR, polymerase chain reaction; HDAC, histone deacetylase

Key words: gastric carcinoma, histone methylation, Suv39H1, siRNA interference
BCL-2, pro-caspase-9, pro-caspase-3 and C-myc. Suv39H1 may be a potential gene target for anti-gastric carcinoma therapy.

\section{Introduction}

Histone modifications have been reported to include acetylation, phosphorylation, methylation, ADP ribosylation and ubiquitination (1). Histone methylation indicates the methylation on lysine $(\mathrm{K})$ and arginine residues on the $\mathrm{N}$-terminal of histones $\mathrm{H} 3$ and $\mathrm{H} 4$. Histone tail modifications can be markers for both active and repressed chromatin and are also interdependent. For histone lysine methylation, there are currently five described positions in the N-terminal of histone $\mathrm{H} 3$ (K4, K9, K27 and K36) and histone H4K20. Methylation of histone $\mathrm{H} 3$ lysine 4 (H3K4), H3K36 and H3K79 are mainly correlated with transcriptional stimulation, whereas methylation of $\mathrm{H} 3$ lysine 9 (H3K9), H3K27 and H4K20 comprise imprints for transcriptionally silent chromatin $(2,3)$. Histone methylation, especially tri-methyl modification, was once believed to be irreversible, and to have an impact on long-term epigenetic memory. Yet, recent studies have discovered several demethylases, such as LSD-1, LSD-2 and JHDM1, which can demethylate histone and cause epigenetic changes (4-6).

Histone methylation on lysines is important for transcriptional silence. Suv39H1 is the first described histone methyltransferase (HMT) which is the mammalian homologues of S. pombe Clr4 and Drosophila Su (Var) 39, two proteins that are involved in silencing by pericentric heterochromatin (7-10). The Suv39H1 can be classified as the major H3K9 tri-methylating enzyme which appears to use an H3K9 0 monomethylated residue as the in vivo substrate. This interpretation is supported by in vitro HMT assays indicating a much higher preference for H3K9 monomethylated substrates (11).

Suv39H1 may be involved in tumorigenesis. The PML-RAR $\alpha$ fusion protein causes acute promyelocytic leukemia (PML), presumably via redistribution of the Suv39H1 to PML bodies and perturbed histone lysine methylation at RAR $\alpha$ target promoters (12). Other examples include association of heterochromatic HMTs with the tumor suppressor retinoblastoma protein (RB) (13). Furthermore, the SET domain genes EZH2 and MLL1 are involved in the progression of prostate cancer and mixed-lineage leukemia $(14,15)$. 
Table I. Clinical significance of Suv39H1 expression in the gastric carcinoma cases $(n=175)$.

\begin{tabular}{|c|c|c|c|c|}
\hline \multirow[b]{2}{*}{ Group } & \multicolumn{2}{|c|}{ Suv39H1 protein expression } & \multirow[b]{2}{*}{$\chi^{2} / \mathrm{t}$} & \multirow[b]{2}{*}{ P-value } \\
\hline & Positive & Negative & & \\
\hline Gender (Male/Female) & $97 / 30$ & $36 / 12$ & 0.036 & $>0.05$ \\
\hline Body mass index (BMI) & $20.1 \pm 3.4$ & $21.4 \pm 3.6$ & 2.09 & 0.37 \\
\hline Age (years) & $60.5 \pm 12.3$ & $57.1 \pm 9.8$ & 2.04 & 0.34 \\
\hline Pathological type & & & 0.493 & $>0.05$ \\
\hline Papillary adenocarcinoma & 14 & 6 & & \\
\hline Tubular adenocarcinoma & 67 & 25 & & \\
\hline Poorly differentiated adenocarcinoma & 20 & 8 & & \\
\hline Signet-ring cell carcinoma & 6 & 3 & & \\
\hline Mucinous adenocarcinoma & 20 & 6 & & \\
\hline Level of differentiation & & & 11.27 & $<0.05$ \\
\hline Intermediate-highly differentiated & 65 & 38 & & \\
\hline Poorly differentiated & 62 & 10 & & \\
\hline Depth of infiltration & & & 28.43 & $<0.05$ \\
\hline $\mathrm{T} 1+\mathrm{T} 2$ & 14 & 23 & & \\
\hline $\mathrm{T} 3+\mathrm{T} 4$ & 113 & 25 & & \\
\hline Lymphatic metastasis & & & 10.71 & $<0.05$ \\
\hline No & 12 & 14 & & \\
\hline Yes & 115 & 34 & & \\
\hline Tumor-node-metastasis stage & & & 0.071 & $>0.05$ \\
\hline $\mathrm{I}+\mathrm{II}$ & 58 & 23 & & \\
\hline III+IV & 69 & 25 & & \\
\hline
\end{tabular}

Chakraborty et al reported that Suv39H1 methylated H3K9 and affected DNA transcriptional activity through interaction with the nut region of AML protein, leading to the development of acute myeloid leukemia (16).

Aberrant histone methylation has not been well characterized in human disease, especially in gastric carcinoma. The function of Suv39H1 is still not well known. In the present study, we investigated the expression of Suv39H1 and histone methylation in gastric carcinoma, and evaluated the correlation between Suv39H1, histone methylation and clinicopathological features, and prognosis in gastric carcinoma. Furthermore, we applied the siRNA technique to deplete Suv39H1 and measure consequent histone modification, gene transcription, cell proliferation and apoptosis in MGC-803 cells.

\section{Materials and methods}

\section{Collection of patient samples and data}

Ethics statement. The present study consisted of a total of 175 gastric carcinoma patients who underwent curative surgical resection at the Department of Surgery of Zhangzhou Affiliated Hospital of Fujian Medical University between January 2001 and December 2011. The surgically removed tissue samples were collected from all participants who had signed an informed consent form indicating their willingness to participate. Experimental procedures were approved by the
Ethics Committee of Zhangzhou Affiliated Hospital of Fujian Medical University.

Pathological stage was determined by the tumor-nodemetastasis (TNM) classification. Gastric carcinoma was classified according to the degree of differentiation, depth of infiltration, lymphatic invasion and TNM stage as described in Table I. Patient samples from chronic superficial gastritis $(n=30)$, chronic atrophic gastritis $(n=30)$ and moderate-severe atypical hyperplasia $(n=30)$ were used as control.

Tissue microarray construction and immunohistochemistry. A representative tumor section paraffin block (donor block) was collected from each case, and two tissue cores $(2 \mathrm{~mm}$ in diameter) were obtained using a trephine apparatus. Since gastric carcinoma frequently shows histological heterogeneity, we sampled duplicate tissue cores from separate areas in individual paraffin-embedded gastric tumors for better representation of the tumor. Trephinated paraffin tissue cores were then arranged in a new recipient paraffin block (tissue array block). Cores containing tumor in $>50 \%$ of the area were considered adequate. Immunohistochemical staining was performed using commercially polyclonal rabbit anti-histone antibodies to histone methyltransferase Suv39H1, tri-methylhistone H3K9 and H3K4 (Upstate Biotechnology, Lake Placid, NY, USA). Tissue array blocks were sectioned at a thickness of $4 \mu \mathrm{m}$ and mounted on pre-coated glass slides. The sections 
were deparaffinized and hydrated prior to immunohistochemistry. The immunohistochemical S-P method was performed according to the manufacturer's protocol. Tissues positive for all of the purchased antibodies were used as positive controls; sections prepared with phosphate-buffered saline instead of the primary antibody were used as negative controls. Positive controls exhibited a brown color in the nuclei. Chevallier's semi-quantity system analysis was used for the calculation of the immunohistochemistry results. Results are presented as the sum of scores presenting color density and the percentage of stained cells. According to color density, non-stained cells were scored as 0 ; slightly stained as 1 ; intermediate-stained as 2 and strongly stained as 3 . When the number of positive cells was $<25,25-50,>50-75$, or $>75 \%$, the immunoreactivity was scored as $1+, 2+, 3+$ and $4+$, respectively. The two scores for color density and the number of positive cells were added for each slide. A sum of 0 was consider negative; 1-2, +; 3-4, ++; $5-6,+++$ and 7 as ++++ . If the sum of the two scores was $\leq 2$, it was considered negative staining; $>2$ was considered positive staining. The scores for each patient group were averaged.

Cell line and culture. Human gastric carcinoma MGC-803 cells were purchased from the American Type Culture Collection. Cells were cultured in $10 \%$ fetal bovine serum and RPMI-1640 containing L-glutamine under $37^{\circ} \mathrm{C}$, saturated humidity and $5 \% \mathrm{CO}_{2}$. Cells were subcultured every 3-5 days. The subculture of cells was performed using $0.25 \%$ trypsin to digest the attached cells for 2-3 min.

RNA interference. The approach by transient transfection using Lipofectamine ${ }^{\mathrm{TM}} 2000$ was employed to deplete the Suv39H1 gene in the MGC-803 cell line. Suv39H1 siRNA sense: 5'-CGUGGAUUGUCUCAGGGAATT-3' and antisense 5'-UUCCCUGAGACAAUCCACGTG-3' were synthesized by Shanghai GenePharma Co., Ltd. (China). Transfection with siRNA was performed according to the Lipofectamine ${ }^{\mathrm{TM}} 2000$ manufacturer's protocol (Invitrogen, Carlsbad, CA, USA). Inducible MGC-803 cells $\left(1 \times 10^{5}\right.$ cells/well) were seeded onto 24-well plates, (Costar Life Science, Acton, MA, USA) and transiently transfected with 0 , or 60,120 or $240 \mathrm{nmol} / 1$ Suv39H1 siRNA. All experiments were conducted in triplicate using independent cultures. Both total RNA and protein were extracted after a 24-h transfection.

Real-time polymerase chain reaction (PCR). Total RNA was extracted from samples of $1 \times 10^{6}$ cells using TRIzol (Invitrogen). The quantity and quality of RNA samples were measured by absorbance at 260 and $280 \mathrm{~nm}$. RNA samples with an A260:A280 ratio 1.8-2.0 were stored at $-80^{\circ} \mathrm{C}$ until use. cDNA synthesis was performed using an Avian Myeloblastosis Virus Reverse Transcriptase kit, according to the manufacturer's protocol (Promega, Madison, WI, USA). $\beta$-actin was used as the internal control. Primers used in the PCR amplifications were: Suv39H1 forward, 5'-TGCGTATCCTCAAGCAGTTCC-3' and Suv39H1 reverse, 5'-CCGTCCAGGTCCACCTCATTC-3'; $\beta$-actin forward, 5'-CTCCTTAATGTCAC GCACGATTTC-3' and $\beta$-actin reverse, 5'-CTACAATGAGCTGCGTGTGGC-3'. Amplicon size was 217 base pairs (bp) and 517 bp for Suv39H1 and $\beta$-actin, respectively. PCR reaction conditions were: $94^{\circ} \mathrm{C}$ for $45 \mathrm{sec}, 56^{\circ} \mathrm{C}$ for $1 \mathrm{~min}, 72^{\circ} \mathrm{C}$ for $80 \mathrm{sec}$ which was repeated for 30 cycles. The PCR-amplified products were electrophoresed on $1.0 \%(\mathrm{w} / \mathrm{v})$ agarose gels with $1 \mu \mathrm{g} / \mathrm{ml}$ ethidium bromide. Experiments were repeated twice.

Cell proliferation as measured by MTT assay. The MGC-803 cells were seeded at a density of $1 \times 10^{5} /$ well in 96-well culture dishes (Costar Life Science). After 0, 24, 48, 72 and $96 \mathrm{~h}$ transfection $(\mathrm{n}=5)$ with $0,30,60,120,240$ or $480 \mathrm{nmol} / \mathrm{l}$ Suv39H1 siRNA, cell proliferation was measured using MTT assays $(0.5 \mathrm{mg} / \mathrm{ml}$; Sigma). The spectrophotometric absorbance of the samples was determined by using an Ultra Multifunctional Microplate Reader (Tecan, Durham, NC, USA) at 492 and $630 \mathrm{~nm}$. Suppression ratio was also calculated. The experiment was repeated in triplicate.

Apoptosis as detected by TUNEL assay. Cells at a logarithmic phase of growth were transfected with negative control siRNA and 60, 120 and $240 \mathrm{nmol} / 1 \mathrm{Suv} 39 \mathrm{H} 1 \mathrm{siRNA}$, and were seeded in 6-well plates $\left(1 \times 10^{6}\right.$ cells/well; Costar Life Science) with a sterile cover glass placed at the bottom of each well. Cells were used for the detection of apoptosis $24 \mathrm{~h}$ after transfection by TUNEL, according to the manufacturer's protocol (DeadEnd $^{\mathrm{TM}}$ Fluorometric TUNEL System; Promega).

Western blot analysis. Total protein lysate and western blot analysis were performed as previously described (17). Briefly, MGC-803 cells were plated on culture dishes and transfected with Suv39H1 siRNA at 60, 120 and $240 \mathrm{nmol} / 1$ for $24 \mathrm{~h}$. Control cells were incubated in the medium with $\mathrm{Na}_{2} \mathrm{CO}_{3}$ using the same time points. After incubation, total proteins were prepared from each culture condition with a lysis buffer containing freshly prepared protease inhibitors. The protein concentration was then measured using the BCA protein assay (Pierce, Rockford, IL, USA). Cell extracts were subjected to $12 \%$ SDS-PAGE and electrophoretically transferred to nitrocellulose membranes. The membranes were incubated with monoclonal anti-acetyL-HistoneH3, anti-acetyL-Histone H4, tri-methyl-Histone H3K9, Suv39H1 (Upstate, USA), BCL-2, pro-caspase-9, pro-caspase-3 and C-myc antibodies (Santa Cruz, Santa Cruz, CA, USA). After being washed with TBS, the membranes were incubated with the secondary antibody conjugated with peroxidase. The signal was then detected using the chemiluminescence detection system (Pierce) and analyzed by a color image analysis system (AlphaDigiDoc; Alpha Innotech).

Statistical analysis. The Student's t-test for mean and standard deviation or the Mann-Whitney test for median and range were performed for comparisons between the groups in regards to continuous data. Comparisons among groups regarding categorical data were analyzed by performing the Chi-square test. All data were analyzed using the SPSS, version 16.0 computer program (SPSS, Inc., Chicago, IL, USA), and the significance of these differences was defined as $\mathrm{p}<0.05$.

\section{Results}

Overexpression of Suv39H1 and histone tri-methylation of H3K9 in gastric carcinoma. We assessed the staining score for Suv39H1, tri-methylation of H3K9 and H3K4 in 175 cases 


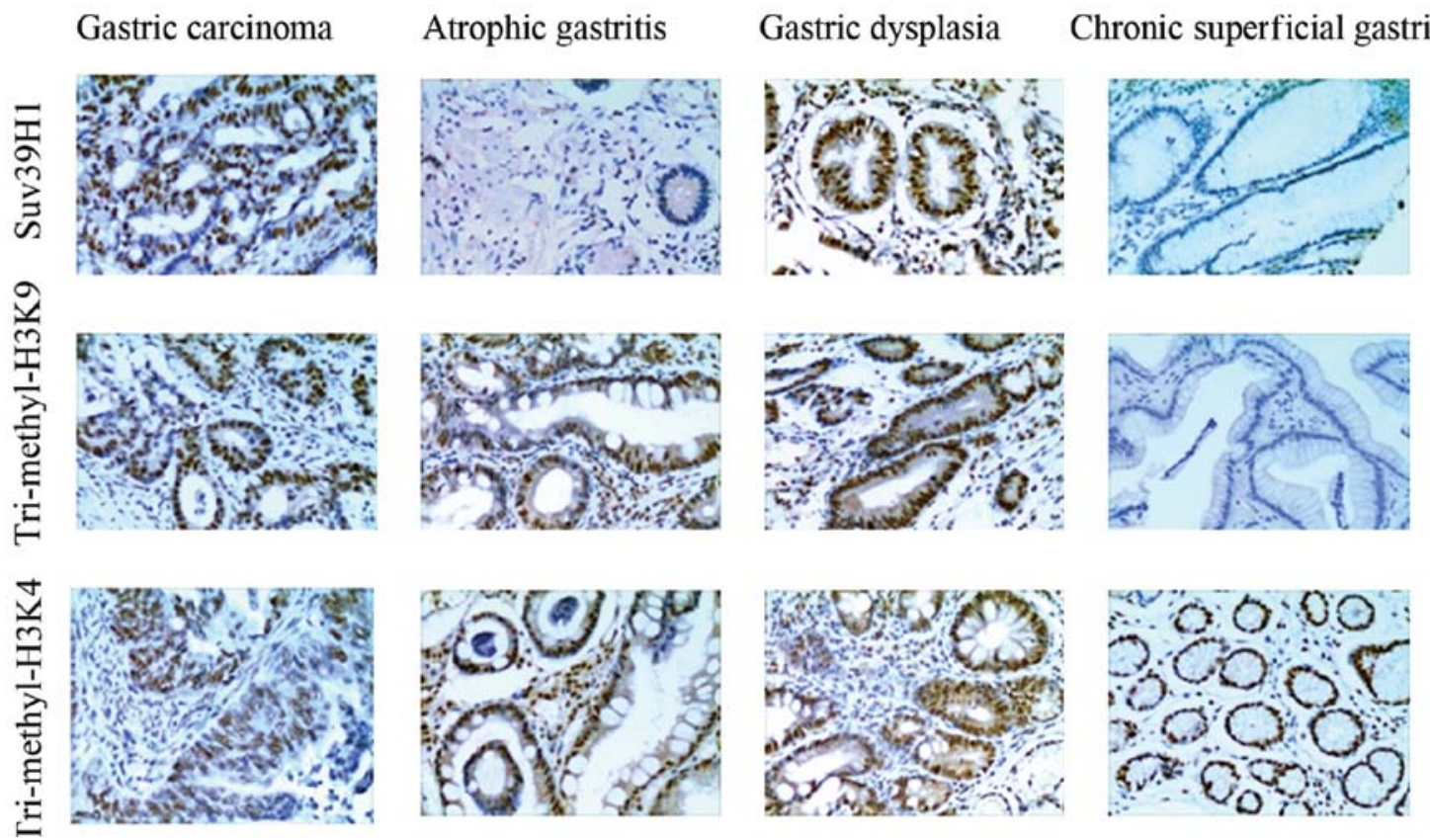

Figure 1. Expression of Suv39H1, tri-methyl-H3K9 and tri-methyl-H3K4 in gastric carcinoma and benign gastric diseases. The expression of Suv39H1 and H3K9 in gastric carcinoma was higher than that in chronic superficial gastritis, chronic atrophic gastritis and moderate-severe dysplasia, $\mathrm{p}<0.05$. The histone tri-methylation of H3K4 in gastric carcinoma was similar to that in the other disease tissues, p>0.05. H3K9, histone H3 lysine 9; H3K4, histone H3 lysine 4 .
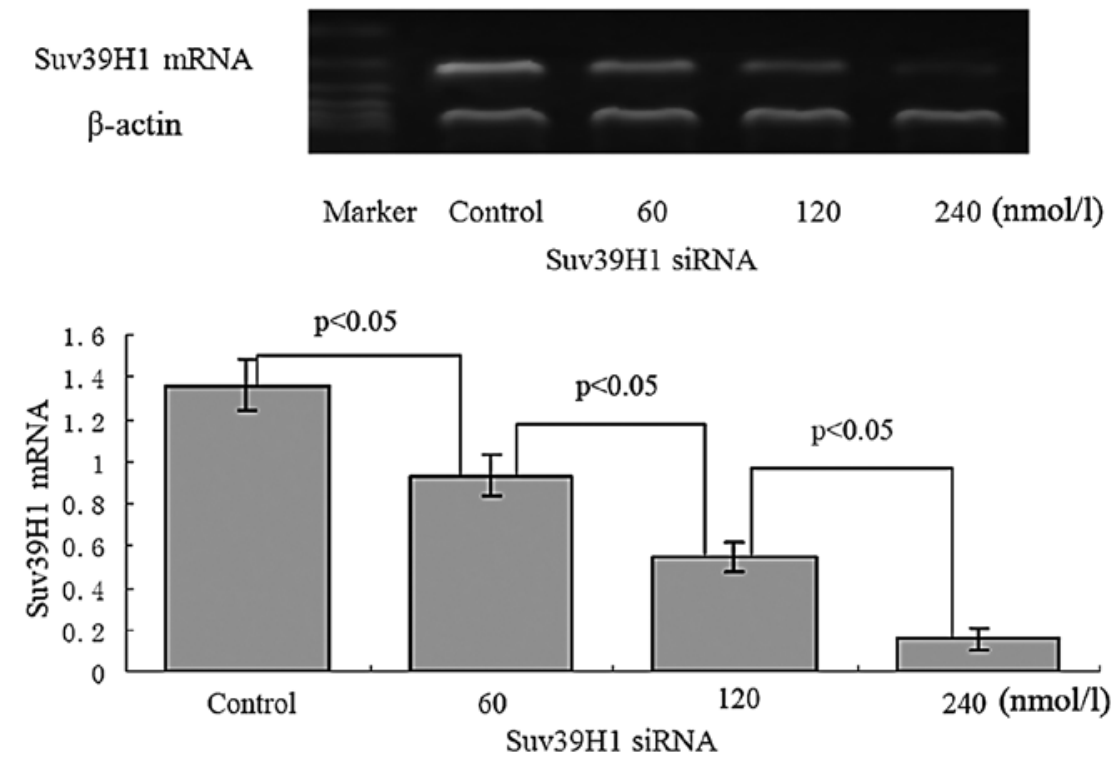

Figure 2. Silencing efficiency of Suv39H1 siRNA on expression of the Suv39H1 gene. Amplification of Suv39H1 mRNA was attenuated in a concentration-dependent manner.

of gastric carcinoma. The expression of Suv39H1 in gastric carcinoma was $72.57 \%$, higher than that in the chronic superficial gastritis $(33.33 \%, \mathrm{p}<0.05)$, chronic atrophic gastritis $(30.00 \%, \mathrm{p}<0.05)$ and moderate-severe dysplasia $(46.67 \%$, $\mathrm{p}<0.05$ ) (Fig. 1). The expression of histone tri-methylation of $\mathrm{H} 3 \mathrm{~K} 9$ in gastric carcinoma was $85.47 \%$, higher than that in the chronic superficial gastritis $(36.67 \%, \mathrm{p}<0.05)$, chronic atrophic gastritis $(33.33 \%, \mathrm{p}<0.05)$ and moderate-severe dysplasia (53.33\%, p<0.05) (Fig. 1). The histone tri-methylation of H3K4 in gastric carcinoma was $59.43 \%$, which was similar to that of chronic superficial gastritis $(46.67 \%, \mathrm{p}>0.05)$, chronic atro- phic gastritis $(60.00 \%, \mathrm{p}>0.05)$ and moderate-severe dysplasia $(50.00 \%, \mathrm{p}>0.05)$ (Fig. 1).

Correlation of Suv39H1 and histone tri-methylated H3K9 with clinicopathological variables in the gastric carcinoma cases. To evaluate the correlation between the histone methylation status and various clinicopathological data, we divided the level of staining scores into two groups: negative (score $\leq 2$ ) and positive (score $>2$ ). The data showed that the Suv39H1 status was positively correlated with the degree of differentiation $\left(\chi^{2}=11.27, p<0.05\right)$, depth of infiltration $\left(\chi^{2}=28.43, p<0.05\right)$ 
Table II. Clinical significance of histone H3K9 methylation in the gastric carcinoma cases $(n=175)$.

\begin{tabular}{|c|c|c|c|c|}
\hline \multirow[b]{2}{*}{ Group } & \multicolumn{2}{|c|}{ Histone $\mathrm{H} 3 \mathrm{~K} 9$ protein expression } & \multirow[b]{2}{*}{$\chi^{2} / \mathrm{t}$} & \multirow[b]{2}{*}{ P-value } \\
\hline & Positive & Negative & & \\
\hline Gender (Male/Female) & $113 / 34$ & $20 / 8$ & 0.381 & $>0.05$ \\
\hline Body mass index (BMI) & $20.3 \pm 3.6$ & $21.3 \pm 3.8$ & 2.13 & 0.39 \\
\hline Age (years) & $59.3 \pm 11.3$ & $58.1 \pm 10.7$ & 2.20 & 0.56 \\
\hline Pathological type & & & Fisher's precise probability & 0.865 \\
\hline Papillary adenocarcinoma & 16 & 4 & & \\
\hline Tubular adenocarcinoma & 78 & 14 & & \\
\hline Poorly differentiated adenocarcinoma & 23 & 5 & & \\
\hline Signet-ring cell carcinoma & 7 & 2 & & \\
\hline Mucinous adenocarcinoma & 23 & 3 & & \\
\hline Level of differentiation & & & 7.46 & $<0.05$ \\
\hline Intermediate-highly differentiated & 80 & 23 & & \\
\hline Poorly differentiated & 67 & 5 & & \\
\hline Depth of infiltration & & & 16.65 & $<0.05$ \\
\hline $\mathrm{T} 1+\mathrm{T} 2$ & 23 & 14 & & \\
\hline $\mathrm{T} 3+\mathrm{T} 4$ & 124 & 14 & & \\
\hline Lymphatic metastasis & & & 6.33 & $<0.05$ \\
\hline No & 17 & 9 & & \\
\hline Yes & 130 & 19 & & \\
\hline Tumor-node-metastasis stage & & & 20.84 & $<0.05$ \\
\hline $\mathrm{I}+\mathrm{II}$ & 57 & 24 & & \\
\hline $\mathrm{III}+\mathrm{IV}$ & 90 & 4 & & \\
\hline
\end{tabular}

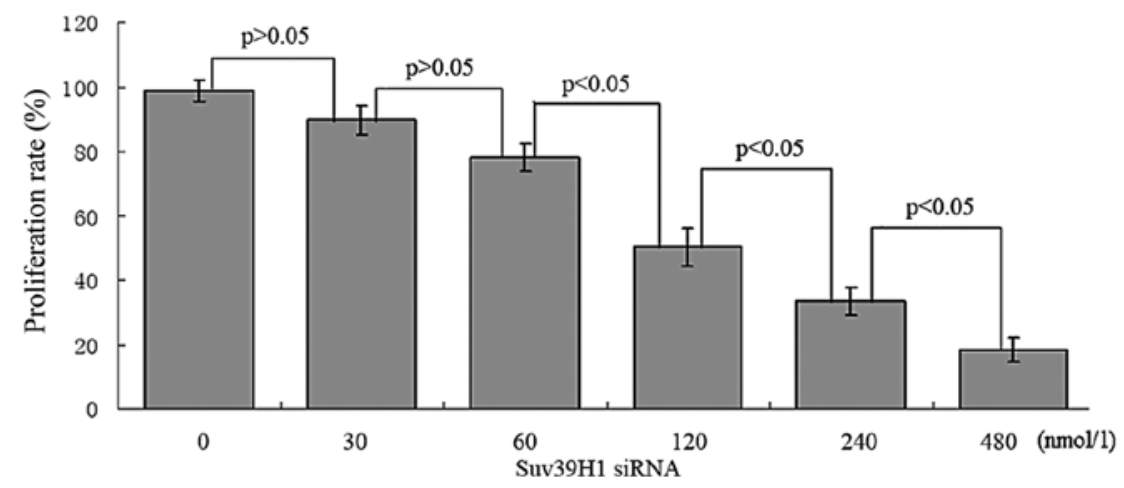

Figure 3. Assessment of cell proliferation after transfection of MGC-803 cells with Suv39H1 siRNA. Cell proliferation was inhibited in the MGC-803 cells after $24 \mathrm{~h}$ of transfection with the indicated concentrations of Suv39H1 siRNA.

and lymphatic invasion $\left(\chi^{2}=10.71, \mathrm{p}<0.05\right)$. The Suv39H1 status was not correlated with TNM stage $\left(\chi^{2}=0.071, \mathrm{p}>0.05\right)$, age, $(\mathrm{t}=2.04, \mathrm{p}>0.05)$, gender $\left(\chi^{2}=0.036, \mathrm{p}>0.05\right)$, body mass index $(\mathrm{BMI})(\mathrm{t}=2.09, \mathrm{p}>0.05)$ or pathological type $\left(\chi^{2}=0.493\right.$, $\mathrm{p}>0.05$ ) (Table I).

The tri-methylated $\mathrm{H} 3 \mathrm{~K} 9$ status was positively correlated with the degree of differentiation $\left(\chi^{2}=7.46, p<0.05\right)$, depth of infiltration $\left(\chi^{2}=16.65, \mathrm{p}<0.05\right)$, lymphatic invasion $\left(\chi^{2}=6.33\right.$, $\mathrm{p}<0.05)$ or TNM stage $\left(\chi^{2}=20.84, \mathrm{p}<0.05\right)$. It was not correlated with age $(\mathrm{t}=2.20, \mathrm{p}>0.05)$, gender $\left(\chi^{2}=0.381, \mathrm{p}>0.05\right)$, BMI $(\mathrm{t}=2.13, \mathrm{p}>0.05)$ or pathological type $(\mathrm{p}=0.865)$ (Table II).

Silencing efficiency of the Suv39H1 gene following transfection of Suv39H1 siRNA in MGC-803 cells. After 24 h of transfection of MGC-803 cells with Suv39H1 siRNA at 60, 120 and $240 \mathrm{nmol} / \mathrm{l}$, the amplification of Suv39H1 mRNA was attenuated in a concentration-dependent manner. Gray value (to $\beta$-actin) showed that the amplification of Suv39H1 was 


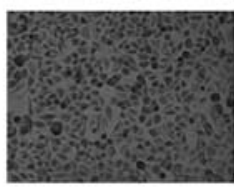

Control

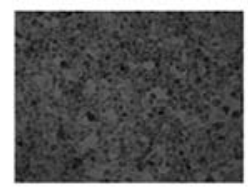

60

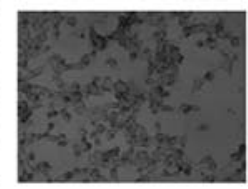

120

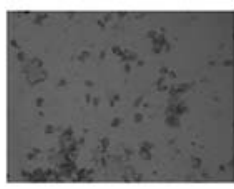

$240(\mathrm{nmol} / \mathrm{l})$

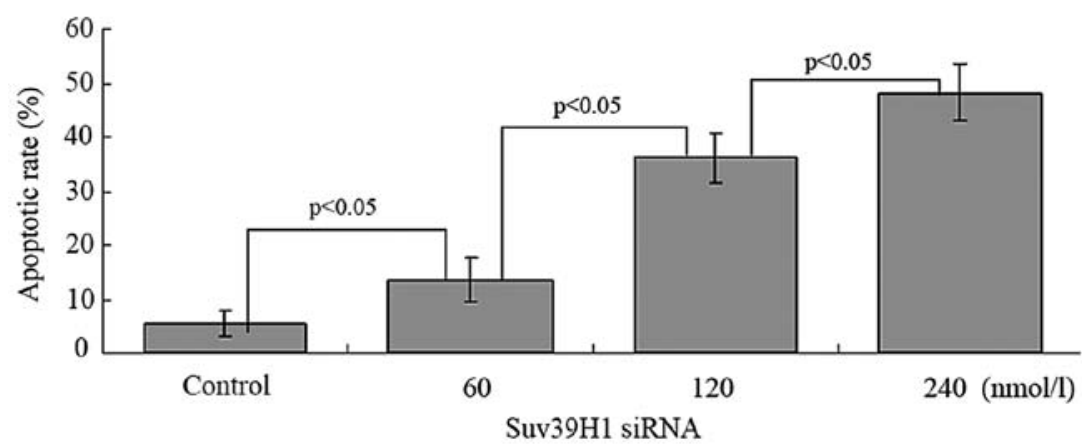

Figure 4. Assessment of cell apoptosis after transfection of MGC-803 cells with Suv39H1 siRNA. Cell apoptosis was induced after $24 \mathrm{~h}$ of transfection with the indicated concentrations of Suv39H1 siRNA in the MGC-803 cells.

BCL-2

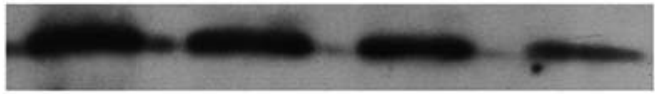

Pro-caspase-3

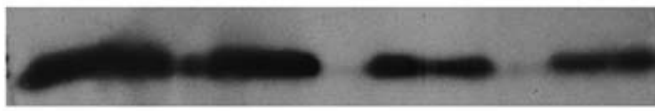

Pro-caspase-9

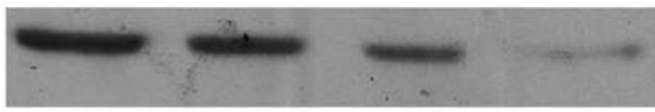

C-myc

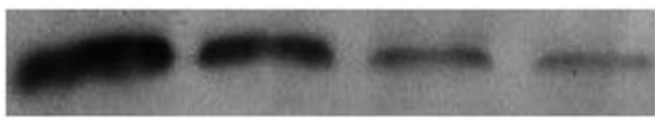

$\beta$-actin

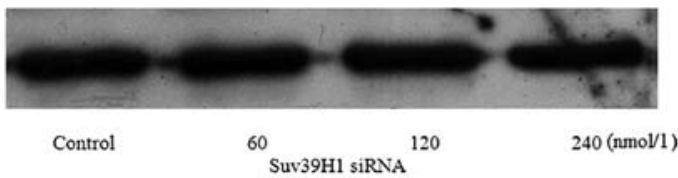

Figure 5. Expression of apoptosis-related proteins after transfection with Suv39H1 siRNA in MGC-803 cells. The apoptosis-related proteins were inhibited after $24 \mathrm{~h}$ of transfection with Suv39H1 siRNA at the indicated concentrations. The protein levels of BCL-2, pro-caspase-3 pro-caspase- 9 and C-myc were suppressed after transfection with Suv39H1 siRNA.

$0.93 \pm 0.10$ at $60 \mathrm{nmol} / 1,0.55 \pm 0.07$ at $120 \mathrm{nmol} / 1$ and $0.16 \pm 0.05$ at $240 \mathrm{nmol} / 1 \mathrm{respectively,} \mathrm{compared} \mathrm{to} \mathrm{the} \mathrm{control}(1.36 \pm 0.12)$ $(\mathrm{p}<0.05)$ (Fig. 2).

Suv39H1 siRNA inhibits cell proliferation and promotes apoptosis in MGC-803 cells. Suv39H1 siRNA significantly suppressed cell proliferation. Twenty-four hours after transfection with Suv39H1 siRNA, $\sim 50.12 \pm 5.98 \%$ reduction in cell density was noted at $120 \mathrm{nmol} / 1,33.37 \pm 4.13 \%$ at $240 \mathrm{nmol} / 1$ and $18.35 \pm 3.96 \%$ at $480 \mathrm{nmol} / \mathrm{l}$ (Fig. 3).

The apoptotic cells exhibited brown staining in the nucleus. The apoptotic rate was $5.4 \pm 2.3,13.5 \pm 4.1,36.3 \pm$ 4.6 and $48.3 \pm 5.4 \%$ after $24 \mathrm{~h}$ of transfection with Suv39h1 siRNA at $0,60,120$ and $240 \mathrm{nmol} / 1$, respectively. The apoptotic rate was increased in a concentration-dependent
Suv39H1
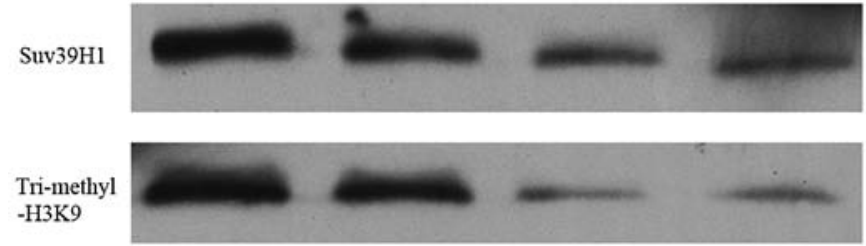

Act-H3

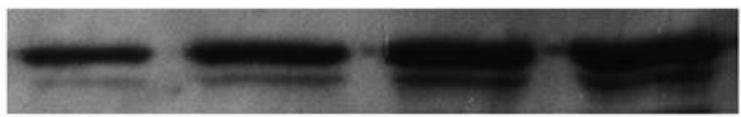

Act-H4

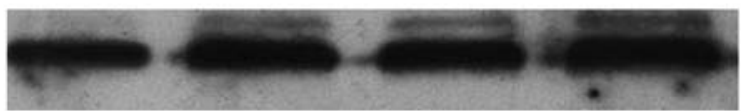

$\beta$-actin

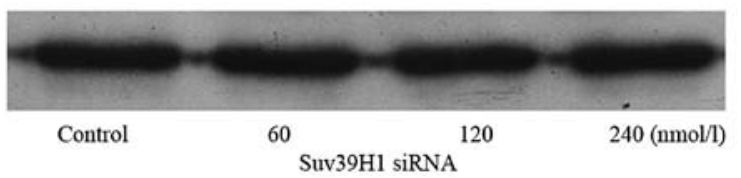

Figure 6. Expression of Suv39H1, tri-methyled-H3K9, acetylation of H3 (Act-H3) and H4 (Act-H4) after transfection with Suv39H1 siRNA. The modulation of Suv39H1, histone methylation and acetylation after transfected with Suv39H1 siRNA for 24 h in MGC-803 cells. Suv39H1 siRNA downregulated Suv39H1 and histone tri-methylated H3k9, and upregulated histone acetylation of $\mathrm{H} 3$. Histone $\mathrm{H} 4$ acetylation was not affected.

manner $(\mathrm{p}<0.05)$ (Fig. 4). We further assessed expression of the apoptosis-associated proteins: BCL-2, pro-caspase-3, procaspase-9 and C-myc. Suv39H1 siRNA significantly inhibited BCL-2, pro-caspase-3, pro-caspase-9 and C-myc (Fig. 5).

Suv39H1 siRNA modulates histone tri-methylation of H3K9 and acetylation of $\mathrm{H3}$ and $\mathrm{H} 4$. Protein of Suv39H1, and histone tri-methylated $\mathrm{H} 3 \mathrm{~K} 9$ were downregulated, while acetylated H3 was upregulated after a $24 \mathrm{~h}$ transfection with Suv39H1 siRNA, when compared with the control. The relative (to $\beta$-actin) gray value showed that Suv39H1 was $1.18 \pm 0.1$, $0.82 \pm 0.08,0.43 \pm 0.12,0.4 \pm 0.11$ and tri-methylated $\mathrm{H} 3 \mathrm{~K} 9$ was 
$1.21 \pm 0.11,0.89 \pm 0.09,0.26 \pm 0.12$ and $0.25 \pm 0.10$; Act-H3 was $0.6 \pm 0.05,0.91 \pm 0.04,1.22 \pm 0.11$ and $1.61 \pm 0.10$ in the control, and at $60,120,240 \mathrm{nmol} / 1 \mathrm{Suv} 39 \mathrm{H} 1 \mathrm{siRNA}$, respectively $(\mathrm{p}<0.05)$. There was no change in histone $\mathrm{H} 4$ acetylation. The expression of Act-H4 was $1.22 \pm 0.05,1.31 \pm 0.10,1.25 \pm 0.06,1.33 \pm 0.11$ in the control and at 60, 120, $240 \mathrm{nmol} / 1$ Suv39H1 siRNA, respectively ( $\mathrm{p}>0.05)$ (Fig. 6).

\section{Discussion}

$\mathrm{H} 3 \mathrm{~K} 9$ methylation is a major component of gene regulation and chromatin organization. Suv39H1 methylates H3K9 at the pericentric heterochromatin region and participates in the maintenance of genome stability. In the present study, we described the overexpression of Suv39H1 and histone tri-methylated H3K9 in gastric carcinoma. Suv39H1 and histone tri-methylated H3K9 were positively correlated with the degree of differentiation, depth of infiltration and lymphatic invasion in gastric carcinoma. The expression of histone methylated H3K9 was correlated with TNM stage. This indicates that overexpression of Suv39H1 and histone tri-methylated H3K9 may be involved in the initiation and development of gastric carcinoma. This is an initial study of Suv39H1 in gastric carcinoma and its clinicopathological characteristics.

The role of Suv39H1 in pericentric heterochromatin has been extensively investigated, but only a few studies have suggested the involvement of Suv39H1 in tumorigenesis. Overexpression of Suv39H1 is associated with colon cancer (18). We previously found that aberrant histone methylation occurs in acute leukemia and lymphoma (19). Park et al studied 261 gastric adenocarcinoma samples and concluded that tri-methylation of $\mathrm{H} 3 \mathrm{~K} 9$ was positively correlated with tumor stage, lymphovascular invasion, cancer recurrence, and a higher level of $\mathrm{H} 3 \mathrm{~K} 9$ tri-methylation was correlated with a poor survival rate (20). Multivariate survival analysis showed that H3K9 tri-methylation status is an independent prognostic factor. Differential expression of Suv39H1 was reported in different types of cancer, and a prominent increase in the expression of Suv39H1 was observed in preneoplastic nodules and liver tumors induced by methyl deficiency in rats $(21,22)$. The mechanism of Suv39H1's tumorigenesis involves Suv39H1-associating partner molecule HP1 which is able to interact with RB (23), raising the possibility that Suv39H1 could be directly linked to specific tumor-suppressor proteins $(24,25)$. This may be the reason why overexpression of Suv39H1 and H3K9 is involved in carcinogenesis.

We further silenced the Suv39H1 gene by transfection of Suv39H1 siRNA into gastric carcinoma MGC-803 cells to study the effect on cell growth and apoptosis. The results demonstrated that silencing of the Suv39H1 gene inhibited cell proliferation and induced cell apoptosis in the MGC-803 cells, along with downregulation of pro-caspase-3 and -9, BCL-2 and $\mathrm{C}$-myc, which are related to the apoptosis pathway. The escape from replicative senescence in Suv39H1 transgenic erythroblasts was previously found to be correlated with reduced amounts of the 'antiproliferative' cell cycle regulator p21, deregulated abundance of RB, aberrant cytoplasmic levels of p53 and elevated expression of the p53-destabilizing protein $\mathrm{mdm}(26,27)$. Suv39H1 is targeted to promoters of cell-cycle control genes by RB and also induces the silencing of S-phase genes through $\mathrm{H} 3 \mathrm{~K} 9$ methylation in differentiating cells $(13,28)$. H3K9 methylation is a prerequisite for DNA methylation to occur $(29,30)$. Loss of Suv39H1/2 in knockout mouse cells also altered the DNA methylation pattern of their pericentric heterochromatin (31).

The present study revealed that suppression of the expression of Suv39H1 not only downregulates H3K9 methylation, but also upregulates histone $\mathrm{H} 3$ acetylation, which is consistent with previous results (32). We previously found that silencing of Suv39H1 upregulated histone acetylated H3K9, $\mathrm{H} 3$ and P15 in HL60 cells. It did not affect H3K27, H3K14 and $\mathrm{H} 4$. Vaute et al found that interaction with histone deacetylase could be mediated by the N-terminus of Suv39H1, which contains a chromodomain (33). Histone deacetylases (HDACs) associated with Suv39H1 may include HDAC1, HDAC2 and HDAC3. Multiple residues on each of the four core histones have been identified as potential modification sites, and some lysine residues, such as $\mathrm{H} 3 \mathrm{~K} 9$, can be either methylated or acetylated. Recent studies have shown that switching acetylation to methylation on $\mathrm{H} 3 \mathrm{~K} 9$ contributes to euchromatin gene silencing in many organisms (34).

In summary, utilizing a large number of specimens from patients with gastric carcinoma, we demonstrated for the first time that Suv39H1 is positively correlated with initiation, development and migration of gastric carcinoma. Suv39H1 is also positively correlated with the level of $\mathrm{H} 3 \mathrm{~K} 9$ methylation in these tissues. In addition, we confirmed that Suv39H1 affects $\mathrm{H} 3 \mathrm{~K} 9$ methylation and $\mathrm{H} 3$ acetylation, and inhibits cell growth and induces cell apoptosis in vitro. The results from this study highlight the potential of $\mathrm{H} 3 \mathrm{~K} 9$ methyltransferases as therapeutic targets for gastric carcinoma.

\section{Acknowledgements}

This study was partly supported by grant-in-aid from the Foundation of Science and Technology of Zhangzhou, Fujian, China (No.Z07014), the Foundation of Science and Technology of Fujian Medical University, Fujian, China (No. FZS08018), the Science Research Foundation of Ministry of Health, United Fujian Provincial Health, and the Education Project for Tackling the Key Research, China (WKJ2008-2-55).

\section{References}

1. Jenuwein $\mathrm{T}$ and Allis CD: Translating the histone code. Science 293: 1074-1080, 2001.

2. Fischle W, Wang Y and Allis CD: Histone and chromatin crosstalk. Curr Opin Cell Biol 15: 172-183, 2003.

3. Lachner M, O'Sullivan RJ and Jenuwein T: An epigenetic road map for histone lysine methylation. J Cell Sci 116: 2117-2124, 2003.

4. Klose RJ, Kallin EM and Zhang Y: JmjC-domain-containing proteins and histone demethylation. Nat Rev Genet 7: 715-727, 2006.

5. Cang S, Ma Y and Liu D: New clinical developments in histone deacetylase inhibitors for epigenetic therapy of cancer. J Hematol Oncol 2: 22, 2009.

6. Tan J, Cang S, Ma Y, Petrillo RL and Liu D: Novel histone deacetylase inhibitors in clinical trials as anti-cancer agents. J Hematol Oncol 3: 5, 2010.

7. Rea S, Eisenhaber F, O'Carroll D, et al: Regulation of chromatin structure by site-specific histone H3 methyltransferases. Nature 406: 593-599, 2000. 
8. Allshire RC, Nimmo ER, Ekwall K, Javerzat JP and Cranston G: Mutations derepressing silent centromeric domains in fission yeast disrupt chromosome segregation. Genes Dev 9: 218-233, 1995.

9. Tschiersch B, Hofmann A, Krauss V, Dorn R, Korge G and Reuter G: The protein encoded by the Drosophila position-effect variegation suppressor gene $\mathrm{Su}(\mathrm{var}) 3-9$ combines domains of antagonistic regulators of homeotic gene complexes. EMBO J 13: 3822-3831, 1994

10. Aagaard L, Laible G, Selenko P, et al: Functional mammalian homologues of the Drosophila PEV-modifier Su(var)3-9 encode centromere-associated proteins which complex with the heterochromatin component M31. EMBO J 18: 1923-1938, 1999.

11. Peters AH, Kubicek S, Mechtler K, et al: Partitioning and plasticity of repressive histone methylation states in mammalian chromatin. Mol Cell 12: 1577-1589, 2003.

12. Di Croce L, Raker VA, Corsaro M, et al: Methyltransferase recruitment and DNA hypermethylation of target promoters by an oncogenic transcription factor. Science 295: 1079-1082, 2002.

13. Nielsen SJ, Schneider R, Bauer UM, et al: Rb targets histone $\mathrm{H} 3$ methylation and HP1 to promoters. Nature 412: 561-565, 2001.

14. Varambally S, Dhanasekaran SM, Zhou M, et al: The polycomb group protein EZH2 is involved in progression of prostate cancer. Nature 419: 624-629, 2002.

15. Milne TA, Briggs SD, Brock HW, et al: MLL targets SET domain methyltransferase activity to Hox gene promoters. Mol Cell 10: 1107-1117, 2002.

16. Chakraborty S, Sinha KK, Senyuk V and Nucifora G: SUV39H1 interacts with AML1 and abrogates AML1 transactivity. AML1 is methylated in vivo. Oncogene 22: 1107-1117, 2003.

17. Ma X, Fang Y, Beklemisheva A, et al: Phenylhexyl isothiocyanate inhibits histone deacetylases and remodels chromatins to induce growth arrest in human leukemia cells. Int J Oncol 28 : 1287-1293, 2006.

18. Kang MY, Lee BB, Kim YH, et al: Association of the SUV39H1 histone methyltransferase with the DNA methyltransferase 1 at mRNA expression level in primary colorectal cancer. Int J Cancer 121: 2192-2197, 2007.

19. Zou Y, Ma X, Huang Y, Hong L and Chiao JW: Effect of phenylhexyl isothiocyanate on aberrant histone $\mathrm{H} 3$ methylation in primary human acute leukemia. J Hematol Oncol 5: 36, 2012.

20. Park YS, Jin MY, Kim YJ, Yook JH, Kim BS and Jang SJ: The global histone modification pattern correlates with cancer recurrence and overall survival in gastric adenocarcinoma. Ann Surg Oncol 15: 1968-1976, 2008.

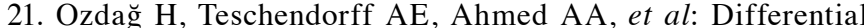
expression of selected histone modifier genes in human solid cancers. BMC Genomics 7: 90, 2006.

22. Pogribny IP, Ross SA, Tryndyak VP, Pogribna M, Poirier LA and Karpinets TV: Histone H3 lysine 9 and H4 lysine 20 trimethylation and the expression of Suv4-20h2 and Suv-39h1 histone methyltransferases in hepatocarcinogenesis induced by methyl deficiency in rats. Carcinogenesis 27: 1180-1186, 2006.

23. Williams L and Grafi G: The retinoblastoma protein - a bridge to heterochromatin. Trends Plant Sci 5: 239-240, 2000.

24. Dunaief JL, Strober BE, Guha S, et al: The retinoblastoma protein and BRG1 form a complex and cooperate to induce cell cycle arrest. Cell 79: 119-130, 1994.

25. Trouche D, Le Chalony C, Muchardt C, Yaniv M and Kouzarides T: RB and hbrm cooperate to repress the activation functions of E2F1. Proc Natl Acad Sci USA 94: 11268-11273, 1997.

26. Cheng M, Olivier P, Dieh1 JA, et al: The p21(Cip1) and p27(Kip1) CDK 'inhibitors' are essential activators of cyclin D-dependent kinases in murine fibroblasts. EMBO J 18: 1571-1583, 1999.

27. Czvitkovich S, Sauer S, Peters AH, et al: Over-expression of the SUV39H1 histone methyltransferase induces altered proliferation and differentiation in transgenic mice. Mech Dev 107: 141-153, 2001.

28. Ait-Si-Ali S, Guasconi V, Fritsch L, et al: A Suv39h-dependent mechanism for silencing $\mathrm{S}$-phase genes in differentiating but not in cycling cells. EMBO J 23: 605-615, 2004.

29. Tamaru H and Selker EU: A histone H3 methyltransferase controls DNA methylation in Neurospora crassa. Nature 414: 277-283, 2001

30. Jackson JP, Lindroth AM, Cao X and Jacobsen SE: Control of CpNpG DNA methylation by the KRYPTONITE histone H3 methyltransferase. Nature 416: 556-560, 2002.

31. Lehnertz B, Ueda Y, Derijck AA, et al: Suv39h-mediated histone H3 lysine 9 methylation directs DNA methylation to major satellite repeats at pericentric heterochromatin. Curr Biol 13: 1192-1200, 2003.

32. Czermin B, Schotta G, Hülsmann BB, et al: Physical and functional association of SU(VAR)3-9 and HDAC1 in Drosophila. EMBO Rep 2: 915-919, 2001.

33. Vaute O, Nicolas E, Vandel L and Trouche D: Functional and physical interaction between the histone methyl transferase Suv39H1 and histone deacetylases. Nucleic Acids Res 30: 475-481, 2002.

34. Lachner $\mathrm{M}$ and Jenuwein $\mathrm{T}$ : The many faces of histone lysine methylation. Curr Opin Cell Biol 14: 286-298, 2002. 